\title{
6
}

\section{GREEN ADVOCACY AND THE CLIMATE AND ENERGY POLICY ACCESS IN CENTRAL EASTERN EUROPE}

\author{
Szczepan Czarnecki, Emilia Piotrowska, \\ and Rafat Riedel
}

\section{Introduction}

Combating climate change by reducing greenhouse gas emissions, improving energy efficiency, and promoting wider usage of renewable energy sources is of the highest importance on the EU's political agenda. The European Green Deal is one of the most ambitious priorities announced in President Ursula von der Leyen's political guidelines. However, many countries from the post-Soviet bloc still remain coal-dependent, and their visions to move away from fossil fuels substantially vary from those promoted by the EU, which are heavily focused on renewables.

Decisions impacting the environment, climate, and energy are supported or contested by various interested parties. Businesses and industry may lobby for laxer standards, less stringent enforcement, and later compliance deadlines; whereas, green activists lobby against them (Heyes \& Liston-Heyes, 2005). They instead advocate for lower emissions, stricter norms of environmental protection, and more urgent enforcement. The threat of impending environmental EU regulations forces stakeholders to choose the timing and levels of strategic responses on a continuum from passive to active (Clement, Bamford \& Douglas, 2008).

Together with the growing body of research dedicated to this topic, scholars have become better informed about green advocacy (GA) movements and their impact on the policy process (Heyes \& King, 2020). In the post-communist world, in which the culture of political participation remains at relatively low levels, GA has its own specifics, making environmental policy one of the most intriguing in the region. This has stimulated scholarly interest in the Central and Eastern Europe (CEE) advocacy organizations, their origin, resources, ways of operating, and contribution to the legitimacy and accountability of political decision-making. Still, the governmental - societal relationship in the climate 
and energy domain notoriously remains an under-studied field, which requires further scientific exploration. Additionally, although scholars of GA often make comparisons to other interest organizations, there has been little systematic analysis of what distinguishes GA groups from other interest groups operating in energy and climate policy domains. This chapter aims to fill this research gap, by focusing on CEE.

The shared experience of the post-communist world (central planning and authoritarian rule) includes, among other things, a common legacy of environmental neglect, inefficient energy usage, limited deposits of natural resources, and increasing energy competition and prices. While environmental concerns, as exemplified by the climate change issue, are at the forefront of the political debate, GA organizations focused on a green future across CEE occupy a somewhat ambiguous position in the spectrum of climate and energy stakeholders. They are a relatively new phenomenon and promoting an ecological agenda pits them against the current status quo agents - at least in some countries of the region, such as Poland. However, such groups enjoy a special mandate from the EU, as their environmental acquis and financial resources provide them with new tools to reach their aims (Börzel \& Buzogany, 2010). GA groups by nature share an ambition to shape energy and climate policies. They may help to formulate and implement an environmentally friendly political course by recognizing and building public awareness about specific problems and solutions. However, it is critical for them to gain access to the policy-making apparatus, which is the focus point of this analysis.

Therefore, this chapter explores the position of GA groups compared to other energy and climate advocacy groups. We focus on GA in four selected CEE countries - the Czech Republic, Hungary, Poland, and Slovenia - and examine what kind of resources (including financial stability, levels of professionalization, and various types of expertise) enable them to gain access to executive bodies, i.e., governing parties and regulatory authorities. Methodologically, the chapter relies on descriptive and inferential statistics using survey data.

In the following, we outline the theoretical framework based on the resource mobilization literature with special attention to its linkages to access to executive bodies. Then, we provide an overview of the GA landscape in CEE, which has blossomed in the past years. In the next section, we explain our research design by introducing the hypotheses, their operationalization, and how we test them. The data analysis is followed by a discussion and concluding remarks.

\section{Resource mobilization and executive bodies - a theoretical framework}

The question of interest group representation is strongly rooted in the social sciences, and the roles and interactions of social actors have been the subject of interest of public policy researchers for years. Various theoretical approaches and perspectives are applied in interest group research, which include both the studies 
of their types and functions, as well as institutional conditions and related strategies of interest representation. There is also an extensive and growing literature on interest organizations in the environmental context and, more generally, GA as social movement, civic society 'syndromes, or interest group is an increasingly popular object of scientific inquiry.

The role of GA in the policy process can be understood by applying several theories, including identity-oriented theories, social responses, resource mobilization, and others. This study is rooted in resource mobilization theory, which focuses on the salience of acquired resources (e.g., monetary, staff, expertise, etc.) and the ability to use them. This approach correlates closely with rational-choice explanations, as it perceives policy stakeholders as rational decision-makers who weigh costs and benefits when deciding whether taking action is worth the time and effort.

Scholars employ a variety of analytical lenses when investigating interest groups' linkages with the policy-making process. Rational-choice assumptions which are at the core of this chapter - highlight the added value of access strategies. Sociological institutionalism views interest group engagement largely as an effect of participatory norm diffusion and the logic of appropriateness. Interest groups' participation in the policy-making process is conditioned by many exogenous and endogenous factors (Dür \& De Bièvre, 2007). The first group of factors is the institutional environment, understood as the nature of the political system, the infrastructure of intermediation of interests, the degree of openness of the policy-making apparatus, election funding, or applicable lobbying regulations. The second group of factors is strongly connected with the interest groups' characteristics such as the size, degree of concentration or dispersion, internal structure, nature of membership, financial resources, expert knowledge, hierarchy of power, level of representativeness, and ability to take collective action or various aspects of professionalization. The third group of factors refers to the nature of a given policy in which stakeholders are involved, including its level of relevance, salience, and complexity.

In this chapter, we rely in particular on the resource-dependency theory to examine to what extent selected resources (including finances, levels of professionalization, various types of expertise, etc.) condition access to executive bodies. Scholars have produced a great deal of studies testing how various types of resources determine the interest groups' access to the policy-making apparatus (Beyers \& Kerremans, 2007), often relying on resource mobilization (McCarthy \& Zald, 1977) and exchange relationship theories (Berkhout, 2013). In this approach, bureaucrats and interest groups interact due to the mutual need for resources. However, the ability to provide resources is strongly connected with the interest group type.

According to the access and exchange of resources model (Bouwen, 2004), resources are the most important factor conditioning access to decision-making processes. There is an ongoing exchange process between interest groups and decision-makers, while selected resources, such as expert knowledge, constitute 
the good desired by decision-makers (Woll, 2007). A prominent hypothesis in interest group research is that resource-rich groups are more successful. Resource exchange can therefore either result in stronger influence over policy outputs or at least greater access to decision-makers (Dür \& De Bièvre, 2007).

A normative assessment of the political role of interest groups depends on how much power interest groups have, and how power is distributed among different groups (Dür \& De Bièvre, 2007). Several of them are worth mentioning, for example, the alignments with political actors or the resources available for mobilization. Internal group resources, such as the number of members and financial and professional staff resources can affect their options for engaging in intensive efforts to influence politics (Baumgartner \& Leech, 1998; Christiansen \& Nørgaard, 2006). The lack of resources might force groups to restrict themselves to a narrow range of activities, and abundant resources may enable groups to engage in a wide range of activities (Gais \& Walker, 1991).

Since measuring influence is a problematic enterprise in political science, an alternative approach can be taken (Huberts \& Kleinnijenhuis, 1994). Using 'the logic of access' instead of focusing on impact, we explore the factors that shape access to institutions. Several models can be identified here. The 'direct effect' model captures situations in which the interest groups interact with the government or its branches, directly. The 'mediated effect' model grasps how environmental groups affect public opinion to raise general awareness and consciousness. In this scheme, public opinion acts as an intervening variable between and among societal environmental groups and the governmental policy-making capacity. The 'political alliance model' sees ecological groups using support by powerful allies inside institutional arenas and providing support to governmental officials (Tarrow, 1994). In this approach, organized interests focus on different political arenas in accordance with their goal and then match their resources to the demands of gate-keepers (Binderkrantz, Christiansen \& Pedersen, 2014). In this chapter, we focus exclusively on the 'direct effect' by examining the interest groups' access to two types of executive bodies: political parties in power and public administration. Based on the literature, we assume that the executive is important for energy organizations: according to Gais and Walker (1991), organizations aiming to participate in the preparation and implementation of policies are more likely to approach bureaucrats. Scholars distinguish between the two organizational levels of the executive branch: the political executive (governing party or coalition) and public administration (inter alia regulatory authorities) (Egeberg, 2007). The basis for this distinction is the separation of political (fundamental) decisions belonging to the government from executive and technical decisions (administrative routine) that are the responsibility of the administration.

\section{Green advocacy in Central Eastern Europe}

Research dedicated to GA has been a well-established part of scholarship growing parallel to environmental advocacy evolving on the ground. There are 
interdisciplinary studies focusing on the economic (Heyes \& Liston-Heyes, 2005), political (Grossmann, 2006), societal (Holt, 2019), or business (Hung-Che \& Ching-Chan, 2017) dimensions. Relatively, little has been published on interest groups' impact on the enforcement of environmental law (for a notable exception, see Hofmann, 2019) and even less on the earlier stages of the policy cycle. 'Green Advocacy' as a descriptive term embraces both private and public interest organizations, acting in favor of a green future, no matter if the motivation is profit or idea. The common denominator is raising awareness of environmental issues, promoting green capital and technology (Jones, 2008), protesting greenhouse emissions, and climate protection. Advocacy by various green actors helps to reach new levels of trust and commitment and develop transparency, dialogue, and partnership (Hung-Che \& Ching-Chan, 2017). Such a categorization goes hand in hand with some conceptualizations present in the early political science research in the field, which favored pluralistic explanations of interest group ecosystems, emphasizing their goals over their organizational features and objectives over their incentives (Smith, 1984).

The field of GA research, as well as scholarly investigations on other organized interests, have blossomed in the past decades. There are many streams of scientific investigations addressing various aspects of green activism, its sources, inspirations, ways of manifesting, access to the policy process, its influence on political decisions, and related issues. Some scholars explored factors that determine the formation, mobilization, and dynamics of ecological groups (Steel et al., 2003; Wapner, 1996). Other subfields address whether and how green activists' demands are heard during various phases of the policy formation (Fiorino, 1996; Güney, 2015). Other scholars (Börzel \& Buzogany, 2010; Lafferty \& Meadowcroft, 1996; Mason, 1999) focus on the inclusive capacity of governments when processing specific climate or energy policy issues.

GA groups are a specific type of interest organizations as they engage in the defense of public goods that are not attributed to any specific individual(s) or group(s). They mobilize resources (material, expertise, membership, etc.), exposing themselves to the potential 'free-rider' problem, as the incentives for participation are less individually-attributed than in the case of classical lobbyists. As claimed by Hansen (1985), people are more likely to participate in environmental activism if the object of collective action is the prevention of a 'collective bad', rather than the creation of 'collective good'.

At the beginning of the transition, CEE countries were struggling with the problem of energy dependence, the lack of diversification of energy suppliers, and old energy infrastructure. Most of the efforts during the transition were focused on economic shock therapy and recovery understood as a massive inflow of foreign direct investments. Thus, ecological standards were generally not a priority. Meanwhile, transnational corporations have been recognized as major contributors to environmental problems worldwide (Wescott, 1992). Environmental protection was sacrificed during the process of opening up to the western world. As a result, the carbon intensity of the economic output in most CEE 
countries is above the EU average today. According to the Emissions Database for Global Atmospheric Research, the Czech Republic and Poland emit 0.3 tons of $\mathrm{CO}_{2}$ per $\$ 1,000$ of GDP; Slovenia and Hungary, 0.2 tons.

The post-communist states differed not only in the starting points as regards their energy mixes, but also various aspects of policy-making. The transition process brought about changes and opened up a field for action for various interest groups. Public ownership of the means of production meant that natural resources were often treated as free goods. Environmental problems were attributed to the imperfections in planning and poor economic governance. The specific context of the post-communist transformations affected environmental groups' activity and behavior. Most of them were neglected for many years. Later on, the Europeanization pressures for the energy transition appeared, while the 'climate change' agenda became an influential factor shaping the energy agendas of CEE countries and supporting selected green interest groups.

Despite similarities and the shared post-communist legacy, the energy and climate policies of Poland, the Czech Republic, Hungary, and Slovenia differ. According to the reports of the European Environment Agency, Poland's atmosphere is one of the most contaminated by carcinogenic benzopyrene among all the EU countries, exceeding the concentration of $1 \mathrm{ng} / \mathrm{m}^{3}$. The main cause of high $\mathrm{CO}_{2}$ emissions and dramatically bad air quality is the coal-based power industry (Skoczkowski et al., 2018). No matter who has governed since 1990, the mining sector was always under government protection (see Kubin in this volume). The newest strategic plan for energy by 2040 assumes that the Polish energy mix will be still based on coal (50\%-60\%), renewables $(21 \%-23 \%)$, and nuclear power. In the Czech Republic, coal-fired power plants are the source of approximately $40 \%$ of its produced electricity. The government wants to phase most of it out over the next 20 years, replacing part of it with new nuclear power plants as well as gas, renewables, and energy imports. The attitude of the government toward renewable energy sources is still complex and reflects patterns of externally imposed standards (Gamze \& Petr, 2020). Naturally poor in fossil fuel resources, Hungary is highly dependent on external fossil fuel; as close to $90 \%$ of its total primary energy supply comes from foreign fossil and nuclear sources. It also lags behind other European countries in terms of renewables (Vadovics, 2019). In Slovenia, oil is the main energy source (45\%). Electricity production is based on hydropower, nuclear energy, and coal, and the government plans to maintain this status quo (Živčič, 2019).

The skepticism of these CEE countries to the EU's climate neutrality goal should not only be seen in the light of the tremendous costs of energy transformation and defending the national status quo. Most of these countries are moving toward more green energy usage but at their own conditions and pace. Today, their share of energy from renewable sources is among the lowest across the EU: $11 \%$ in Poland, $12 \%$ in Hungary, $15 \%$ in Czechia, and up to more ambitious 21\% in Slovenia, which is close to the EU average (EUROSTAT, 2018). Common to the countries is their strong declared focus on strengthening other energy 
sources after their initial resistance toward the European Green Deal. While most of them (apart from Poland) pledged to leave carbon as a source of energy, they declared their will to develop nuclear power rather than renewables, which is not in line with the European Commission strategy and might cause further resistance in the future. This is why it is important to shed some light on the GA groups in the region, who seem to be torn between national interests and their own interests, which are consistent with the EU objectives.

\section{Hypotheses, research design, and methods}

Bearing in mind the above-mentioned state of knowledge on GA in CEE as well as theoretical claims on access to the decision-making apparatus, we launch our study of empirical material with the starting assumption that the group type and resources matter for interest group access. Against this background, we derive three more specific hypotheses related to resources.

Expertise is recognized as a key resource in knowledge-intense sectors (Peterson, 2018) such as climate and energy. It remains critical both internally (for group members) and externally (as exchange good for decision-makers) (Beyers, Eising \& Maloney, 2008). However, there are different theoretical expectations regarding various types of expertise and the match between the provided and demanded information (Hanegraaff et al., 2019). According to Bouwen (2004), parliamentarians - who remain under relatively direct electoral control - are likely to favor political support information on voters' preferences, whereas executive decision-makers are more focused on scientific and technical expertise. Other researchers focus rather on the type of interest groups providing the expertise, arguing that citizens' groups are more likely to pass valuable information on public preferences to policy-makers (Flöthe, 2020). The innovative nature of the green transition requires high levels of expertise among environmental activists, renewable energy businesses, and other actors involved in the decision-making process. Based on these findings, we predict that various types of expertise (scientific, legal, and economic) will be positively correlated with interest group access:

Hypothesis 1: Expertise resources facilitate interest group access to executive bodies.

Organizational theories rooted in the sociology of organizations emphasize professionalization as a structure and process that refers, for example, to the creation of positions requiring a high degree of qualification in terms of educational training and relevant working experience (Kubicek \& Welter, 1985). According to Salamon (2012), professionalization is a shift in organizational staffing and operations, representing an increasing reliance on a paid worker with specialized knowledge gained through formal education (Hwang \& Powell, 2009; Salamon, 2012). In other words, professionalization may be understood as a process of transformation of the internal structures of interest groups toward more 
professionalized practices. Some scholars argue that professionalization differs systematically across the interest group types, whereas others suggest that institutional pressures lead to converging professionalization patterns so that different types of groups are similarly professionalized (Klüver \& Saurugger, 2013). The professionalization of interest groups certainly may vary across different sectors of activity. For instance, some groups may be more focused on internal development and member empowerment, whereas other groups will be less oriented toward professionalization. However, in our study, we are less focused on the process of professionalization itself but rather on how increasing professionalization (in terms of human resource and organizational development - two variables covering two aspects of the professionalization) enhances access.

Hypothesis 2: Interest groups with large professionalization resources enjoy better access to executive bodies than less professionalized groups.

Interest groups can also substantially vary in terms of financial resources. This variable is recognized as a typical resource used in influencing the decisionmakers (Woll, 2007). Although some scholars argue that money has little measurable effect on policy outcomes (Baumgartner et al., 2014), we assume that it allows interest groups to literally purchase other resources and therefore can facilitate access to executive decision-making. Moreover, for CEE GA groups, who operate on unfavorable domestic grounds, money can be a critically important resource. The green agenda is exceptionally strong in the EU, and Brussels perceives various types of GA organizations as vital for its democratic decisionmaking process. Hence, it sometimes financially stimulates their involvement in policy-making. The EU fund dependency is understandably one of the main ways in which Europeanization is operationalized in interest group studies (Beyers, 2002; Beyers \& Kerremans, 2007; Dür, 2008; Klüver, 2011; Maloney, Hafner-Fink \& Fink-Hafner, 2018; see Chapter 9 in this volume), making EU funding a legitimate sub-variable in analyzing financial resources in GA in CEE. However, we hypothesize more generally that financial resource-rich organizations will enjoy better access to the policy-making apparatus, having in mind this important sub-variable.

Hypothesis 3: Financial resources of interest groups translate into better access to executive bodies.

To measure the role of selected resources on access to executive bodies, we rely on quantitative research: a large-scale online survey was conducted among the representative samples of interest groups in climate and energy in four respective countries (total $\mathrm{N}=117$ ) (see Introduction and Annex). Unlike conventional scholarly classifications by the nature of interest (diffused/concentrated, public/ private, cause/sectional), we rather employ a wider, ecumenical approach of GA groups, which includes both green business organizations (focused on renewables) and green environmental protection activists. This group is juxtaposed with 
all the other energy policy actors, including general energy organizations as well as fossil and nuclear organizations. This selection is backed by the Green Deal approach for Europe, which promotes renewable energy while pushing national agendas to transform existing energy mixes. Both 'opposing' groups represent a quite similar sample in terms of numbers.

The dependent variable was constructed based on the obtained data regarding 'access to governing parties' and 'access to regulatory authorities'. Access demonstrates not only how inclusive the authorities are but also how influential the concrete interests are. It is a two-way street in which society and politicians meet and interact. As far as access to governmental institutions is concerned, if opportunity structures are perceived by interest organizations as closed, they will refrain from input attempts or try alternative access strategies. Therefore, we asked:

How difficult is it to access governing parties? (1 - extremely difficult, 2 - difficult, 3 - sometimes possible, 4 - easy, and 5 - extremely easy)

How difficult is it to access regulatory authorities? (1 - extremely difficult, 2 - difficult, 3 - sometimes possible, 4 - easy, 5 - extremely easy)

The first independent variable comprises financial resources. We asked respondents to indicate to what extent their organization is focused on fundraising activities compared to 1015 years ago, again using an ordinal scale from 1 to 5 ( 1 - much less, 2 - less, 3 - the same, 4 - more, 5 - much more). In the next step, we asked about the general share of EU funds in their budgets, and for the purposes of the statistical analysis, we recorded these data to present them on an ordinal scale from 1 to 5 (much less - much more). To measure scientific, economic, and legal specialized expertise, we asked our respondents to indicate the importance of provided expertise/information for their influence on policy outcomes using a 1 to 3 ordinal scale (1 - unimportant, 2 - somewhat important, 3 - very important). To measure professionalization, we asked our respondents to what extent their organization is focused on general organizational and human resources development compared to 10-15 years ago, again using an ordinal scale from 1 to 5 ( 1 - much less, 2 - less, 3 - the same, 4 - more, 5 - much more).

We first analyzed our data using descriptive statistics to picture the general trends observable in access to executive bodies. Since the collected data were largely presented on ordinal scales, we carried out an ordinal regression (Polytomous universal model) that incorporates the ordinal nature of the dependent variables.

\section{Data analysis}

In line with the presented research design, we begin with a short descriptive analysis of the dependent variables reflecting the means of access to governing parties and regulatory authorities. In general, for all energy groups across CEE, regulatory authorities seem to be more accessible. Both types of energy organizations aggregately indicated having at least 'sometimes possible' access to regulatory authorities, with other energy interest groups indicating close to 'easy'. 


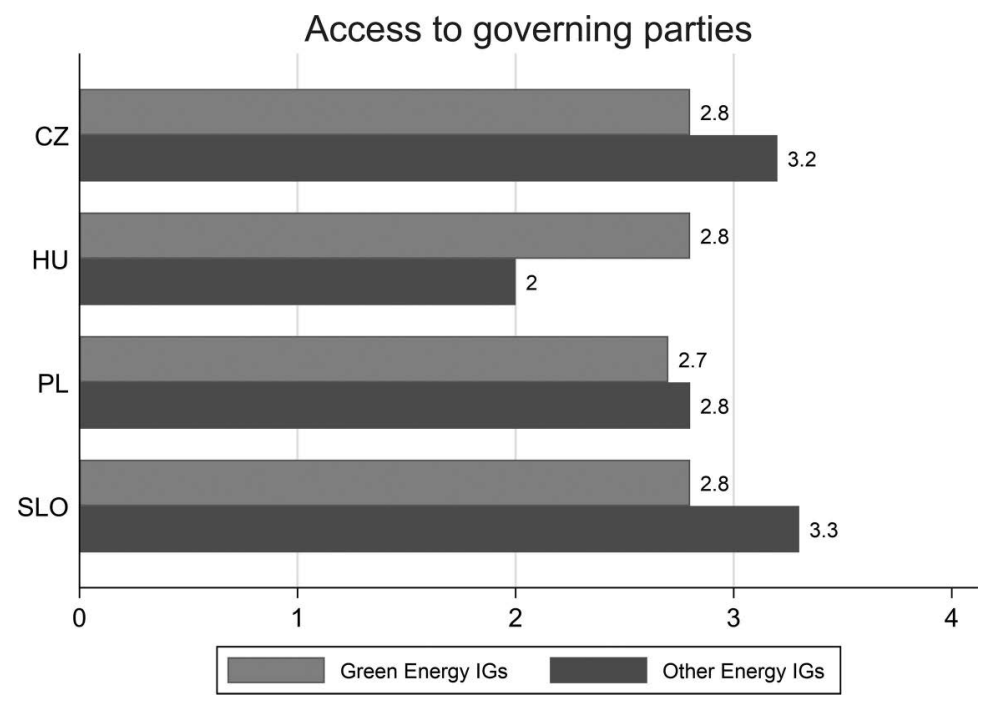

FIGURE 6.1 Access to governing parties.

Note: 1 - extremely difficult, 2 - difficult, 3 - sometimes possible, 4 - easy, 5 - extremely easy.

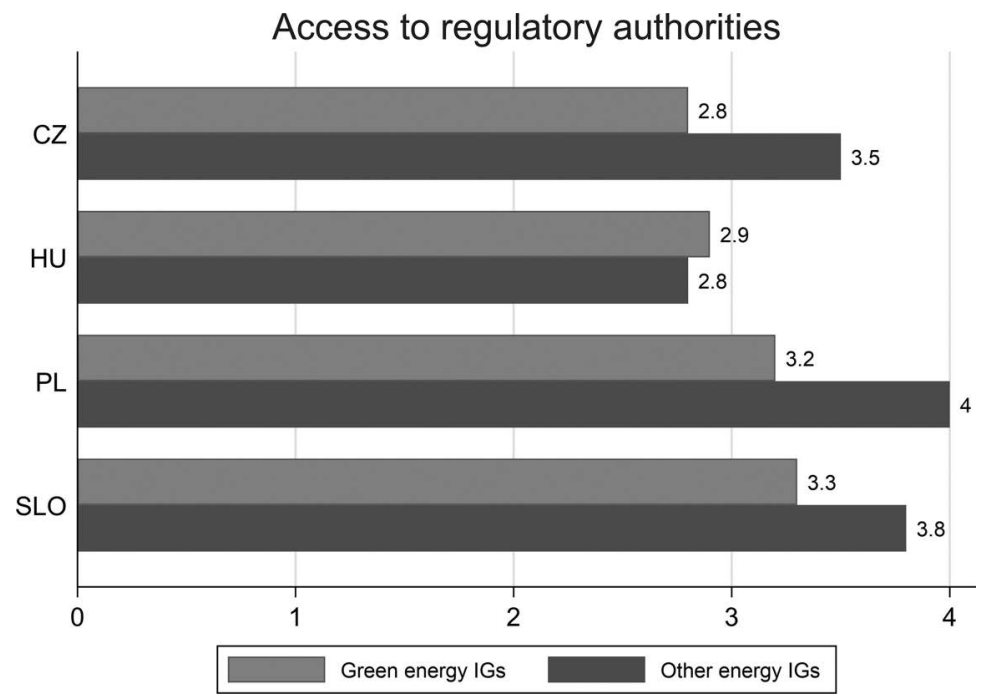

FIGURE 6.2 Access to regulatory authorities.

Note: 1 - extremely difficult, 2 - difficult, 3 - sometimes possible, 4 - easy, 5 - extremely easy.

As regards the access to governing parties, both types indicated that it is 'difficult', with other energy groups indicating close to 'sometimes possible' access. Generally, in every analyzed country, other energy organizations enjoyed better access to both types of executive bodies than GA groups. The only exception was Hungary, where GA groups indicated significantly higher access to governing parties. 
As mentioned above, our two dependent variables are 'access to regulatory bodies' (Table 6.1) and 'access to governing parties' (Table 6.2). Both variables previously measured on a five-point Likert scale were recoded into three-point scales from 1 - (extremely) difficult, 2 - sometimes possible and 3 - (extremely) easy to facilitate our interpretation. As independent variables, we used three groups of explanatory variables, tested in different models. First, we tested the role of different types of expertise for each organization to determine whether provided specialized knowledge may be the key to the political process. Originally measured on three-point scales scientific, economic, and legal expertise was added to our analysis. The second group of independent variables comprises three professionalization factors. We categorized professionalization into three different categories: focus on organizational development, focus on fundraising, and focus on human resources over the last $10-15$ years. We also added an EU fund variable to test whether European funding plays a role for interest groups in accessing policy-makers. We also measured whether the group type in terms of group activity plays a role. Group type variables are dummies coded on 0/1 scales. We also tested whether there is any country-related variance by adding a country categorical variable. To test our hypotheses, we conducted two ordinal regressions that contain five models each (Tables 6.1 and 6.2). Collinearity was tested using Spearman's rank correlation coefficient exhibiting no major collinearity issues among our independent variables.

\section{Group Types}

We started our analysis by testing our predictions for the relationship between the group type and access. In Model I, we tested whether the group type affects access to governing parties (Table 6.1) and regulatory authorities (Table 6.2). The results show that the group type indeed impacts access to executive bodies, especially regulatory authorities. We see that other energy groups enjoy better access to regulatory authorities. The first row of Table 6.2 shows that the estimate parameters -1.05 and their significance at the 0.01 level, suggesting an association between the group type and access executive bodies. With the exception of Model III, in which we test the professionalization variables, and Model V where all the variables were tested, three Models (I, II, and IV) were statistically significant, confirming a relationship between the group type and access to the regulatory bodies. By contrast, in the models, in which we tested the association between the group type and access to the governing parties, the coefficient shows negative values. However, we found no significance at any level in any of the tested models.

\section{Expertise resources}

In Model II (Tables 6.1 and 6.2), we tested whether expertise matters for the groups in accessing relevant political bodies. For both analyzed forms of access, we found out that expertise matters: scientific expertise significantly facilitates access to governing parties (H1). 


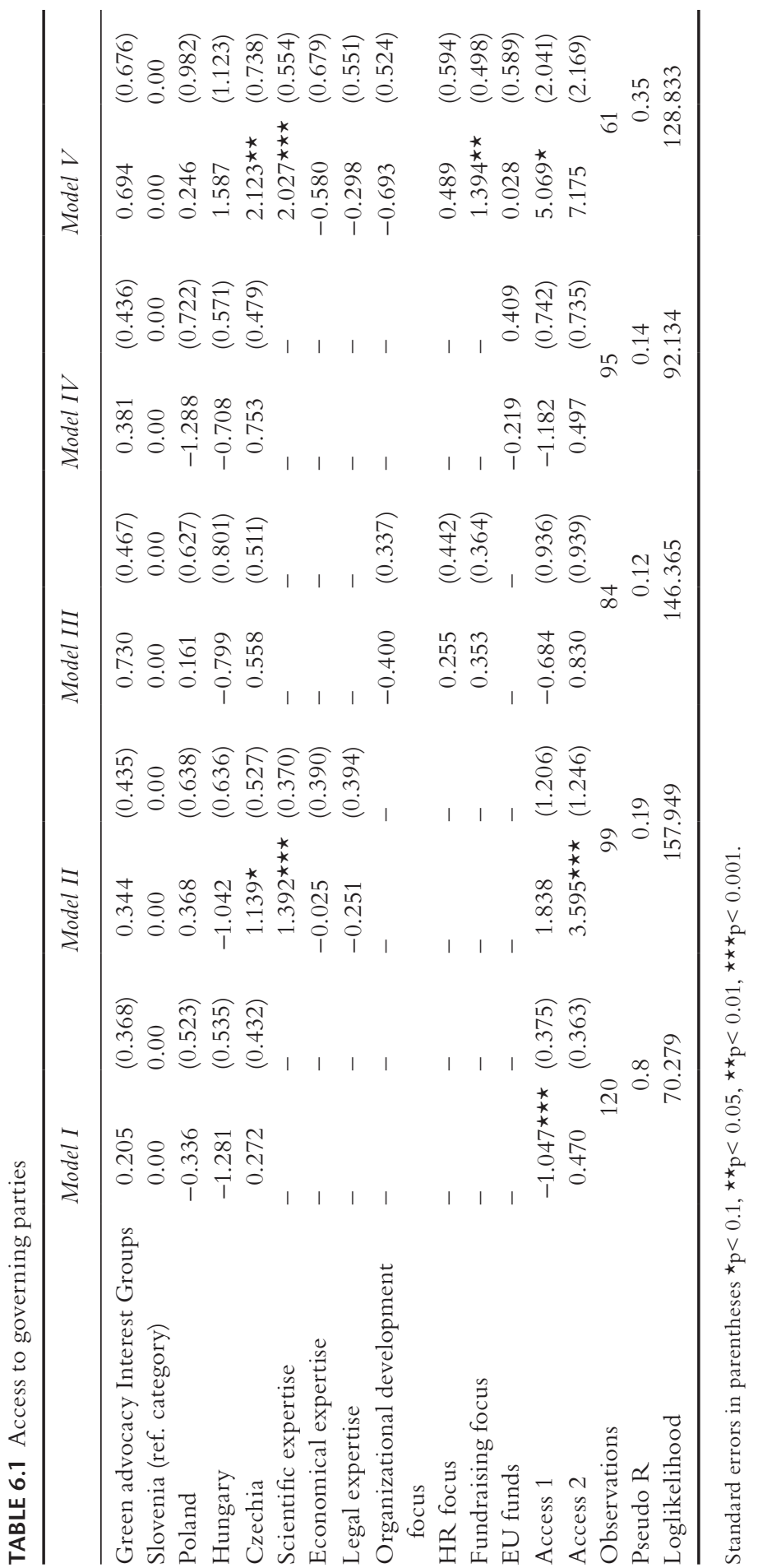




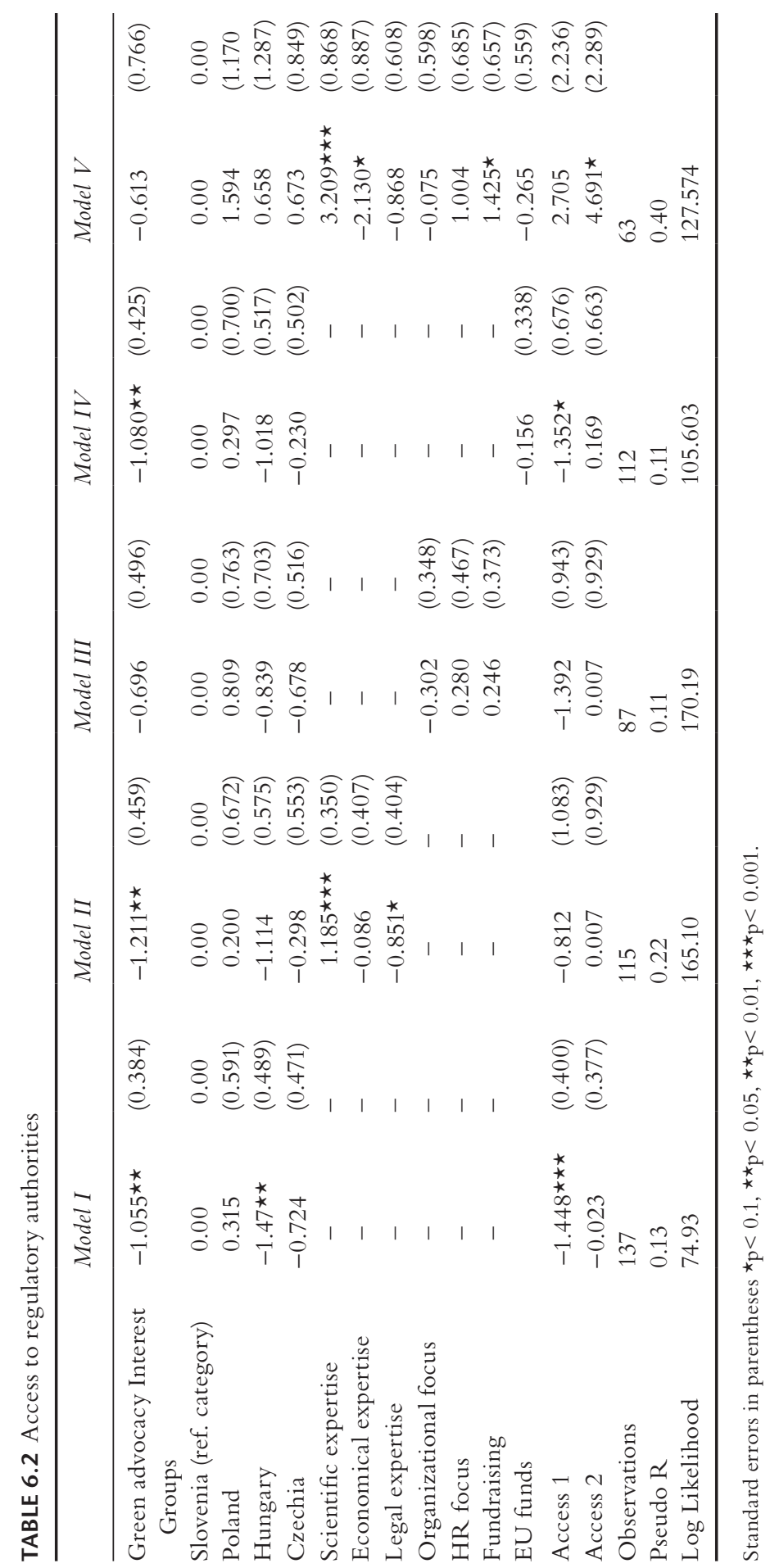


In Model II (Table 6.1), the coefficient takes the positive value of 1.35 and is significant at the 0.001 level, confirming that scientific expertise plays a key role in accessing governing parties. Furthermore, in Model V (Table 6.1), when other variables are added, our estimate parameter takes the value 2.02 with a significance level at 0.001, confirming the strength of the tested association. Legal and economic expertise seems to play a less important role in access to governing parties. The role of scientific expertise is also confirmed in the models in which we tested whether there is an association between 'expertise holders' and access to regulatory bodies (Table 6.2). Again, we found that scientific expertise seems to be a robust factor. In the models where expertise is tested (Model II and Model V), we see that the coefficient takes values from 1.18 to 3.20 and its significance is at the $\mathrm{p}<0.001$ level, which means that the holders of scientific expertise may enjoy better access to the policy-making process. Moreover, we see that our group type estimate parameter is still significant $(\mathrm{p}<0.001)$, taking the value -1.21 and suggesting that other energy interest groups better equipped with scientific expertise enjoy better access. In contrast, legal expertise was found to be significantly negatively associated with access. Considering the effect of expertise on access to the policy formulation process, we found a positive (1.13) and significant association $\mathrm{p}<0.05$ for access to political parties among Czech organizations. We, therefore, assume that expertise plays a more important role in Czechia than in the other analyzed countries. Oppositely, in the model testing the impact of expertise on access to the regulatory bodies, the estimated parameter for Czechia takes a negative value. However, the results are not statistically significant. In both the analyzed cases, it looks like the Hungarian organizations have the lowest access, both to the governing parties (Table 6.1, Model II) and regulatory authorities (Table 6.2, Model II), but yet again, the results are not statistically significant.

\section{Professionalization resources}

In contrast to the expertise variables measured in Model II, two of our professionalization variables (focus on organizational development and focus on human resources) seem to be insignificant in every tested model (Model III, Tables 6.1 and 6.2). Our prediction that the focus on organizational and human resources development would be positively associated with access to executive bodies (H2) was not supported. Especially in Czechia and Poland, the coefficient takes a positive value regarding access to governing parties in the models where the professionalization variable is tested. Yet, our data again suggest that Hungarian organizations struggle with lower access to policy-making bodies compared to their counterparts from Poland, Slovenia, and Czechia. However, the results are not statistically significant. Concerning access to regulatory authorities, we see a rather negative effect of professionalization on access in Czechia and Hungary. 


\section{Financial resources}

We found that a focus on fundraising is positively associated with access to regulatory authorities and governing parties (Tables 6.1 and 6.2) in model five, where we ran the ordinal regression for all dependent variables and control variables. In terms of access to governing parties and regulatory bodies, we found EU funds to be insignificant for access to policy-makers.

\section{Conclusions}

The literature on GA and ecological and environmental movements, in general, has so far generally overlooked CEE (with some noticeable exceptions, see for example, Usacheva, 2012). This chapter partially fills this gap by providing a comparative analysis of CEE GA groups' access compared to other energy interest groups based on freshly obtained empirical data.

At the core of the scientific discourse on GA groups is the idea that they matter for climate and energy policy, as they offer added value both for the content of specific policies and their legitimation. They change the policy milieu within which political decisions are taken (Hood, 1995). Distinguishing between and among different kinds of groups operating within the climate and energy policy process is a natural step toward explaining their success in accessing policy-makers.

The results of our analysis confirm that the group type matters, especially as regards access to regulatory authorities. Other energy interest groups indicated easier access than GA groups in every analyzed country. The highest averages of the access variables can be observed in Poland and Slovenia (for both types of organizations), while lower values were obtained among the Hungarian and Czech groups. Regarding access to governing parties, again other energy groups by average gain easier access than GA groups in Czechia, Poland, and Slovenia. However, in this case, the results from Hungary were opposite, resulting in easier access of green groups to governing parties.

We also strongly drew on the resource-dependency theory, by examining to what extent selected resources (including various types of expertise, aspects of professionalization, and financial stability) condition access to executive bodies. We found that expertise is of crucial importance in accessing regulatory authorities as well as governing parties. Importantly, it relates only to scientific expertise. It is associated with a high level of complexity and innovation, which is required for all stakeholders involved in the green transformation. This needs to be seen in the context of the technologically underdeveloped power industry in most countries of the region. The present energy infrastructure remains, to a large extent, a relic of the past, very often dating back to the pre-1989 era. Decarbonization processes require totally different skills and knowledge than the traditional power generation methods known in CEE. Scientific expertise, focused on the new technologies, matters in accessing authorities and especially regulatory bodies. 
Interestingly, focus on human resources and organizational development turned out to be entirely unimportant for interest groups seeking access to executive bodies. On the contrary, focus on fundraising is positively associated with access to regulatory authorities and governing parties. However, contrary to our expectations, EU funds do not translate into better access at all. This finding is important both for the Europeanization literature and real decision-making 'on the ground'. Financial (or any other) assistance stemming from Brussels creates beneficial conditions for the functioning of the GA organizations. Taking into account the high position of the 'greening economy' on the EU's agenda, it is understandable that supranational authorities care about the wide societal acceptance for the climate crusade. Equally understandable is the financial support for the GA, especially in these EU member states in which the energy mix remains highly carbon-dependent. Undoubtedly, such assistance serves to build public awareness, enhance knowledge distribution, and foster a generally positive atmosphere for pro ecological policy solutions. Nevertheless, our study has shown that funding alone is not an effective tool for GA in gaining access to the core of national executive decision-makers.

\section{References}

Baumgartner, F. R., Berry, J. M., Hojnacki, M., Kimball, D. C., \& Leech, B. L. (2014). Money, priorities, and stalemate: How lobbying affects public policy, Election Law Journal 13(1), pp. 194-209.

Baumgartner, F. R. \& Leech, B. L. (1998). Basic interests: The importance of groups in politics and in political science. Princeton, NJ: Princeton University Press.

Berkhout, J. (2013). Why interest groups do what they do: Assessing the explanatory potential of 'exchange' approaches, Interest Groups \& Advocacy 2(2), pp. 227-250.

Beyers, J. (2002). Gaining and seeking access: The European adaptation of domestic interest associations, European Journal of Political Research 41(5), pp. 585-612.

Beyers, J., Eising, R., \& Maloney, W. (2008). Researching interest group politics in Europe and elsewhere: Much we study, little we know? West European Politics 31(6), pp. 1103-1128.

Beyers, J. \& Kerremans, B. (2007). Critical resource dependencies and the Europeanization of domestic interest groups, Journal of European Public Policy 14(3), pp. 460-481.

Binderkrantz, A., Christiansen, P. M., \& Pedersen, H. H. (2014). Interest group access to the bureaucracy, parliament, and the media, Governance 28(1), pp. 95-112.

Börzel, T. \& Buzogany, A. (2010). Environmental organisations and the Europeanisation of public policy in Central and Eastern Europe: The case of biodiversity governance, Environmental Politics 19(5), pp. 708-735.

Bouwen, P. (2004). Exchanging access goods for access: A comparative study of business lobbying in the European Union institutions, European Journal of Political Research 3(43), pp. 337-369.

Christiansen, P. M. \& Nørgaard, A. S. (2006). Whose agents? Non-governmental organizations in policy-proposing commissions: Agents of government or opposition parties? In D. Braun \& F. Gilardi (Eds.), Delegation in contemporary democracies. London: Routledge, pp. 191-215.

Clement, B., Bamford, C., \& Douglas, T. (2008). Choosing strategic responses to address environmental regulations: Size, perceived influence and uncertainty, Business Strategy and the Environment 17, pp. 493-511. 
Davis, M. S. (2004). Building a movement from scratch: Environmental groups in the Czech Republic, The Social Sciences Journal 41(3), pp. 375-392.

Dür, A. (2008). Interest groups in the EU: How powerful are they? West European Politics 31(6), pp. 1212-30.

Dür, A. \& De Bièvre, D. (2007). The question of interest group influence, Journal of Public Policy 27(1), pp. 1-12.

Egeberg, M. (2007). European government(s): Executive politics in transition? West European Politics 31(5), pp. 235-257.

Faga, J. (2003). Contours of the Czech environmental movement: A comparative analysis of Hnuti Duha (Rainbow Movement) and Jihoceskematky (South Bohemian Mothers), Environmental Politics 12(2), pp. 49-70.

Fiorino, D. J. (1996). Environmental policy and the participation gap. In William M. Lafferty \& James Meadowcroft (Eds.), Democracy and the environment: Problems and prospects. Cheltanham: Edward Elgar, pp. 194-212.

Flöthe, L. (2020). Representation through information? When and why interest groups inform policymakers about public preferences, Journal of European Public Policy 27(4), pp. 528-546.

Gais, T. L. \& Walker, J. L. Jr. (1991). Pathways to influence in American politics. In L. J. Walker Jr. (Ed.), Mobilizing interest groups in America. Patrons, professions and social movements. Ann Arbor: University of Michigan Press, pp. 103-121.

Gamze, T. \& Petr, J. (2020). Policies on renewable energy at the European and national level of governance: Assessing policy adaptation in the Czech Republic, Energy Reports 6(1), pp. 548-553.

Grossmann, M. (2006). Environmental advocacy in Washington: A comparison with interest groups, Environmental Politics 15(4), pp. 628-638.

Güney, T. (2015). Environmental sustainability and pressure groups, quality \& quantity, International Journal of Methodology 49(6), pp. 2331-2344.

Hanegraaff, M., Vergauwen, J., \& Beyers, J. (2019). Should I stay or should I go? Explaining variation in nonstate actor advocacy over time in global governance, Governance 1(18), pp. 287-304.

Hansen, J. M. (1985). The political economy of group membership, American Political Science Review 79, pp. 79-96.

Heyes, A. \& King, B. (2020). Understanding the organization of green activism: Sociological and economic perspectives, Organization \& Environment 33(1), pp. 7-30.

Heyes, A. \& Liston-Heyes, C. (2005). Economies of scope and scale in green advocacy, Public Choice 124, pp. 423-436.

Hofmann, A. (2019). Left to interest groups? On the prospects for enforcing environmental law in the European Union, Environmental Politics 28(2), pp. 342-364.

Holt, D. (2019). Future policy implications and advocacy response to 'big green' advocacy, Pipeline and Gas Journal 1, pp. 29-30.

Hood, G. (1995). Windy craggy. An analysis of environmental interest group and mining industry approaches, Resources Policy 21(1) pp. 13-20.

Huberts, L. W. \& Kleinnijenhuis, J. (1994). Methoden van invloedsanalyse. Amsterdam: Boom.

Hung-Che, W. \& Ching-Chan, C. (2017). What drives green advocacy? A case study of leisure farms in Taiwan, Journal of Hospitality and Tourism Management 33, pp. 103-112.

Hwang, H. \& Powell, W. W. (2009). The rationalization of charity: The influences of professionalism in the nonprofit sector, Administrative Science Quarterly 54(2), pp. 268-298.

Jeffrey, D. W. (2001). The role of the environmental non-governmental organizations in the twenty first century, Biology and Environment: Proceedings of the Royal Irish Academy $101 B(1-2)$, pp. 151-156. 
Jones, V. (2008). Working together for a green new deal, The Nation 17, pp. 12-14.

Klüver, H. (2011). The contextual nature of lobbying: Explaining lobbying success in the European Union, European Union Politics 12(4), pp. 483-506.

Klüver, H. \& Saurugger, S. (2013). Opening the black box: The professionalization of Interest Groups in the EU, Interest Groups \& Advocacy 2, pp. 185-205.

Kubicek, H. \& Welter, G. (1985). Messung der Organisationsstruktur: Eine Dokumentation von Instrumenten zur quantitativen Erfassung von Organisationsstrukturen. Stuttgart: Enke.

Ladrech, R. (2010). Europeanization and national politics. Basingstoke: Palgrave Macmillan.

Lafferty, W. M. \& Meadowcroft, J. (1996). Democracy and the environment: Problems and prospects. Cheltenham: Edward Elgar.

Maloney, W. A., Hafner-Fink, M. \& Fink-Hafner, D. (2018). The impact of the EU accession process and EU funding on the professionalization of national interest groups: The Slovenian case, Interest Groups \& Advocacy 7, pp. 41-60.

Mason, M. (1999). Environmental democracy. New York: St. Martin's Press.

McCarthy, J. D. \& Zald, M. N. (1977). Resource Mobilization and Social Movements: A Partial Theory, American Journal of Sociology 82(6), pp. 1212-1241.

Peterson, M. A. (2018). In the shadow of politics: The pathways of research evidence to health policy making, Journal of Health Politics, Policy and Law 43(3), pp. 341-376.

Renewable Energy Statistics. (2018). Luxembourg: EUROSTAT.

Salamon, L. M. (2012). The resilient sector: The future of nonprofit America. In L. M. Salamon (Ed.), The state of nonprofit America (pp. 3-86). Washington, DC: Brookings Institution Press.

Skoczkowski, T., Bielecki, S., Węglarz, A., et al. (2018). Impact assessment of climate policy on Poland's power sector, Mitig Adapt Strateg Glob Change 23, pp. 1303-1349.

Smith, V. K. (1984). A Theoretical Analysis of the "Green Lobby", American Political Science Review 79, pp. 132-147.

Steel, B. S., Clinton, R. L., \& Lovrich, N. P. Jr. (2003). Environmental politics and policy: A comparative approach. New York: McGraw Hill.

Tarrow, S. (1994). Power in movement. Cambridge: Cambridge University Press.

Thiel, M. \& Uçarer, E. (2014). Access and agenda-setting in the European union: Advocacy NGOs in comparative perspective, Interest Groups \& Advocacy 3, pp. 99-116.

Usacheva, O. A. (2012). Ecological activism in post-soviet Russia and western world, Russian Education and Society 54(4), pp. 78-93.

Vadovics, E. (2019). The energy challenge in Hungary: A need for more complex approaches. In F. Fahy, G. Goggins \& C. Jensen (Eds.), Energy demand challenges in Europe (pp. 83-94). Basingstoke: Palgrave.

Wapner, P. (1996). Environmental activism and world civic politics. Albany: State University of New York Press.

Wescott II, W. F. (1992). Environmental technology cooperation. A quid pro quo for transnational corporations and developing countries, The Columbia Journal of World Business, Fall \& Winter, pp. 144-153.

Woll, C. (2007). Leading the dance? Power and political resources of business lobbyists, Journal of Public Policy 27(1), pp. 57-78.

Živčič, L. \& Tkalec, T. (2019). Slovenia: Focus on energy efficiency, community energy projects and energy poverty. In F. Fahy, G. Goggins \& C. Jensen (Eds.), Energy demand challenges in Europe (pp. 95-104). Cham: Palgrave Pivot. 